\title{
$X V$. On the distribution of thorium in the earth's surface materials
}

\section{G.A. Blanc Ph.D.}

To cite this article: G.A. Blanc Ph.D. (1909) XV. On the distribution of thorium in the earth's surface materials, Philosophical Magazine Series 6, 18:103, 146-148, DOI: $10.1080 / 14786440708636680$

To link to this article: http://dx.doi.org/10.1080/14786440708636680

曲 Published online: 21 Apr 2009.

Submit your article to this journal $\sqsubset \pi$

Џ Article views: 2

Q View related articles $\square$

Citing articles: 2 View citing articles 5 


\section{[ 146$]$}

XV. On the Distribution of Thorium in the Eartl's Surface Materials. By G. A. BLANC, Ph.D. (Rome) *

$\checkmark \mathrm{TE}$ very interesting results communicated by Professor 1 J. Joly in the May number of this Magazine induce me to recali the results of some researches which I have made on the same subject.

In a first note published in February 1908 (Rendic $R$. Accad. d. Lincei, xvii. 1st sem. p. 101, 1908, and also Phys. Zeit. ix. p. 294, 1908) I gave the results of an investigation made hy me in order to determine the amount of thorium contained in unit mass of the soil in Rome. The method consisted in comparing the amounts of excited activity of the thorium type which is produced on a negatively charged wire placed under a vessel covering a given area of soil with that produced when the vessel is placed over a layer of the same earth with which a known quantity of thorium hydroxide in radioactive equilibrium has been intimately mixed.

The result was that the Roman soil must contain ca. $1.45 \times 10^{-5} \mathrm{gr}$. of thorium per gram. It is evident that this value must be considered as a minimum, the experiments having been made with thorium hydroxide, i.e. with the compound which has the strongest emanating power, while we do not know the real state of combination in which thorium is contained in the soil.

In this same note I announced that I had undertaken an investigation with the object of determining, in a more precise and satisfactory manner, the proportion of thorium contained in a certain number of rocks of different nature and origin.

The method followed in this second investigation (Rendic. R. Accad. d. Lincei, xviii. 1st sem. p. 241, 1909) consisted in dissolving, after fusion with alkaline carbonates, about $200 \mathrm{gr}$. of each sample of rock, and collecting the insoluble hydroxides (after having freed the solutions from radium by separating the insoluble sulphates). The hydroxides so obtained showed a noticeable activity when tested by the electroscopic method; this activity inoreased for a few weeks, until a maximum was reached.

This activity could not be due to radium, for the solutions from which the hydroxides were obtained no longer gave any appreciable trace of radium emanation after the insoluble sulphates had been separated; the test was made according

* Conmunicated by J. Joly, E.R.S. 
to the method used by Strutt in his investigations on the amount of radium contained in rocks.

It remained to be seen whether part of the activity could not be due to actinium. Although the presence of traces of actinium cannot be excluded in an absolute way for the moment (careful tests are being carried out presently in order to settle definitely the question), it is certain that the greatest part of the activity shown by my hydroxides is due to thorium. In fact, by using a very sensitive electroscope built for researches on the ionization in closed ressels, I succeeded in obtaining quite distinct phenomena of excited activity from the hydroxides, the rate of decay being that of thorium-excited activity, without any sign of an initial rapid fall which could be attributed to the presence of actinium.

After the activity of the hydroxides had been determined, a given amount of thorium hydroxide in radioactive equilibrium was added to them, and the activity newly determined. In this way the amount of thorium hydroxide necessary to produce the activity originally shown by the hydroxides could be calculated, and therefore also the amount of thorium that must be present in each sample of rock.

The results so far obtained, to which has been added the one obtained in a quite different way for the soil of Rome, are the following :-

$\begin{array}{lll}\text { Vegetal earth (Rome) ........... } & 1.45 \times 10^{-5} \mathrm{gr} . \text { p. gr. } \\ \text { Syenite (La Balma, Biella) ...... } & 8.28 \times 10^{-5} & " \\ \text { Syenite (Bagni, Biella) ........... } & 6.30 \times 10^{-5} & " \\ \text { Granite (Baveno, Lake Major)... } & 3.14 \times 10^{-5} & , \\ \text { Granite (Voges, France) ......... } & 2.07 \times 10^{-5} & "\end{array}$

Finally, in a quite recent paper (Rendic. R. Accad. $d$. Lincei, xviii. 1st sem. p. 289, 1909), although, of course, the small number of specimens of rocks examined by me does not allow us to draw any definitive conclusions, I have calculated the average production of heat due to the products of the thorium family contained in the rocks examined by me, finding that it is about twice the average production of heat due to the products of the uranium-radium family contained in the igneous rocks examined by Strutt. Further, as it is easy to calculate, the average amount of $\gamma$ rays emitted by the products of the thorium family contained in the specimens tested by me is over six times greater than the average amount of $y$ rays emitted by the uranium-radium 
family products contained in the igneous rocks tested by Strutt.

The research described above is being now extended to a large number of specimens of surface materials of the earth's crust, but the results so far obtained, as well as those now published by Professor J. Joly, allow us to conclude that thorium bas certainly a considerable importance as regards terrestrial radioactivity.

Rome, Istituto Fisico della R. Università, May 1909.

XVI. On an Improved Form of Magnetometer and Accessories for the Testing of Magnetic Materials at Different Temperatures. By James G. GraY, D.Sc., F.R.S.E., Lecturer on Physics in the University of Glasgow, and ALEXANDER D. Ross, M.A., B.Sc., F.R.S.Fi., Assistant to the Professor of Natural Philosophy in the University of Glasgow*.

[Plate II.]

T $N$ the usual form of magnetometer the magnetizing 1. solenoid is placed with its axis in the magnetic east and west line passing through the magnetometer-needle. The effect of the current is balanced at the needle by means of a compensating coil connected up in the circuit. This latter coil has its axis coincident, or nearly so, with that of the solenoid. When a feebly magnetic spesimen is under examination the solenoid, and consequently the compensating coil, must of necessity be brought up close to the needle. If large magnetizing currents are employed, any small shift of the coils from their correct positions may be sufficient to seriously impair the balance. In consequence of this the operation of adjusting the position of the compensating coil (the solenoid is usually clamped once for all in a convenient position) is a difficult one, especially as the slight inevitable movement of the coil which results from clamping it in position generally results in the balance being interfered with.

Even if this adjustment be accomplished with the requisite accuracy for the undisturbed position of the magnetometerneedle, it does not necessarily follow that the compensation is complete for the needle in its deflected position. In

* Communicated by Professor A. Gray, F.R.S. : read before the Royal Society of Edinburgh on February 1, 1909. Reprinted from the Proceedirigs of the Rayal Society of Edinburgh. 